\title{
The impact of climate change on the building climatology parameters used for designing the buildings and constructions in Russia
}

\author{
Gregory Vasilyev ${ }^{1 *}$, Victor Gornov ${ }^{1}$, Pavel Konstantinov ${ }^{2}$, Marina Kolesova ${ }^{1}$, Alexander \\ Dmitriev $^{3}$ \\ ${ }^{1}$ INSOLAR-INVEST, 32-3 Bolshaya Filevskaya ul., Moscow, Russia \\ ${ }^{2}$ Lomonosov Moscow State University, Faculty of Geography, Leninskiye Gory, 1, Moscow, 119991, \\ Russia \\ ${ }^{3}$ Plekhanov Russian University of Economics, Stremyannyy per., 36, Moscow, 117997, Russia
}

\begin{abstract}
The data analysis results of long-term measurements of climatic parameters in Moscow and St. Petersburg is presented. The data on change in these parameters during the year over the past 10 years is exposed. The trends have been identified and represented for the following parameters: outdoor temperature, sunshine, snow depth, wind speed, humidity, etc. The duration of heating periods for each studied year and city is considered, as well as crossings through $-2^{\circ} \mathrm{C}$ during these periods. Throughout the research, the impact of climatic changes on the parameters of building climatology, which are used in designing the buildings and constructions in Russia, was determined. The obtained climate information will allow predicting the energy efficiency of operation for various engineering systems in the construction sector, as well as for the long term perspective.
\end{abstract}

\section{Introduction}

The construction of modern, safe and energy-efficient buildings and constructions today is impossible without the use of standardized climatic effects when designing. Those effects are determined in accordance with the approved standard methodology and representing a typical set of climatological data - "typical climatic year". Unfortunately, the correct climate data that could be used as a "typical climate year" in Russia is not available in the current regulatory documents. Engineers still use regulatory documents on building climatology, which were compiled according to climatological databases of the second half of the 20th century. Obviously, these documents do not take into account the climate changes that have occurred in the past decade. As a result, billions in losses are included in the project budgets for the future overstated heating period duration, estimated outdoor temperatures in the coldest five-day period, soil freezing depths, lowered estimated outdoor temperatures in the summer. Furthermore, this is the reason why we the air conditioning systems in are not installed in mass housing today, although it is already obviously necessary. The most displeasing matter is the absence of the hourly calculated values of climatic parameters in

*Corresponding author: eco-insolar@mail.ru 
our regulatory documents on building climatology, primarily regarding the outdoor temperatures. All European standards regarding energy efficiency are based on the use of hourly values of outdoor temperatures, and in our standards it is monthly average. The designer is simply not able to obtain the average hourly calculated temperature values, statistically processed and representing the "typical climatic year" with sufficient reliability. Obviously, it is useless to speak about any reliable control of the achieved energy efficiency indicators without solving the problem of radically updating the regulatory base in the field of building climatology. The lack of standardized hourly values of climatic parameters does not allow designing buildings and structures at a modern level and practically excludes the possibility of using BIM-modeling of HVAC systems (heating, ventilating and airconditioning).

\section{Research methods}

All measurements were carried out at the Meteorological observatory of MSU in accordance with accepted international and domestic standards established by WMO and Roshydromet. Measurements of air temperature in an instrument screen installed at a height of 2 meters above the earth's surface were made using a standard set consisting of station hygrometer, minimum and maximum thermometers TM-1 and TM-2. Continuous monitoring of the diurnal variation was carried out using the daily thermograph M-16. [1] The values of wind speed and direction were obtained at a height of 15 meters, measured using the M63 anemorumbometer. Humidity was measured in an instrument screen using a hair hygrometer, and was also calculated according to a psychrometric installation. The relative humidity was also monitored on a daily scale in continuous mode using a daily M-21M hygrograph. [1] Snow depth was measured by three standard snow stakes in the cold season. Density is measured using a stational ramsonde. [1]

\section{Typical climatic year regarding the average daily outdoor temperature in St. Petersburg}

In order to represent the climatic state of St. Petersburg over the past 10 years, the illustrative and tabular data on meteorological parameters are presented. The RIHMI-WDC data for 2009-2018 was used for calculations, including information on the timing of air temperature, relative humidity, wind direction and speed; data on the snow depth per day and the sunshine duration per month. [2-5]

\subsection{Daily average air temperature}

Table 1. Typical climatic year (in degrees Celsius $-{ }^{\circ} \mathrm{C}$ )

\begin{tabular}{|c|c|c|c|c|c|c|c|c|c|c|c|c|}
\hline & January & February & March & April & May & June & July & August & September & October & November & December \\
\hline 1 & -3.5 & -5.0 & -2.8 & 1.7 & 7.7 & 16.7 & 18.1 & 19.5 & 14.9 & 9.0 & 3.7 & -2.0 \\
\hline 2 & -4.6 & -3.6 & -2.3 & 2.5 & 7.7 & 15.5 & 18.6 & 19.2 & 14.7 & 8.8 & 4.3 & -1.8 \\
\hline 3 & -5.3 & -3.7 & -2.0 & 2.9 & 8.1 & 15.4 & 19.2 & 20.1 & 14.9 & 9.0 & 4.9 & -1.3 \\
\hline 4 & -5.4 & -4.6 & -2.4 & 3.3 & 9.0 & 15.5 & 18.0 & 20.3 & 14.6 & 8.7 & 5.2 & -1.0 \\
\hline 5 & -6.3 & -5.2 & -2.5 & 4.6 & 8.7 & 14.2 & 17.5 & 19.9 & 14.7 & 8.8 & 4.2 & -0.2 \\
\hline 6 & -6.5 & -6.8 & -2.7 & 4.7 & 9.8 & 14.6 & 17.6 & 20.7 & 14.5 & 7.8 & 2.5 & -0.9 \\
\hline 7 & -7.8 & -5.9 & -3.3 & 2.8 & 10.7 & 15.0 & 18.4 & 20.8 & 14.3 & 8.0 & 2.3 & -0.5 \\
\hline 8 & -6.9 & -3.8 & -1.5 & 3.0 & 10.5 & 14.5 & 19.6 & 20.7 & 14.7 & 7.4 & 2.8 & -0.5 \\
\hline 9 & -5.0 & -4.4 & -0.3 & 4.0 & 11.8 & 15.0 & 19.3 & 20.6 & 14.6 & 7.8 & 2.3 & -0.9 \\
\hline 10 & -3.3 & -4.5 & -0.6 & 4.3 & 12.3 & 15.7 & 19.1 & 20.0 & 14.6 & 7.9 & 2.5 & -1.6 \\
\hline 11 & -3.8 & -4.3 & 0.2 & 5.1 & 11.6 & 16.0 & 19.4 & 18.7 & 14.7 & 7.2 & 2.6 & -1.0 \\
\hline 12 & -4.6 & -4.6 & -0.5 & 5.2 & 11.7 & 15.7 & 20.0 & 18.2 & 15.5 & 6.3 & 2.9 & -0.8 \\
\hline 13 & -4.0 & -4.1 & -1.0 & 6.2 & 13.0 & 15.5 & 20.1 & 17.8 & 14.4 & 6.0 & 3.0 & -1.6 \\
\hline 14 & -4.1 & -4.3 & -0.3 & 4.9 & 12.9 & 16.0 & 19.9 & 17.9 & 13.9 & 5.8 & 2.7 & -2.2 \\
\hline 15 & -5.8 & -6.2 & -2.0 & 4.2 & 13.2 & 15.8 & 20.2 & 17.9 & 13.9 & 6.2 & 2.5 & -3.4 \\
\hline 16 & -6.9 & -6.7 & -2.3 & 4.9 & 13.2 & 15.9 & 19.7 & 17.4 & 13.3 & 6.4 & 2.5 & -3.3 \\
\hline
\end{tabular}




\begin{tabular}{|l|l|l|l|l|l|l|l|l|l|l|l|l|}
\hline 17 & -6.8 & -6.4 & -2.2 & 6.0 & 14.5 & 15.4 & 19.4 & 18.1 & 13.0 & 6.3 & 3.4 & -3.7 \\
\hline 18 & -7.3 & -6.0 & -1.2 & 5.3 & 14.9 & 15.7 & 19.1 & 18.1 & 13.0 & 6.3 & 2.6 & -4.2 \\
\hline 19 & -6.4 & -6.1 & -0.3 & 4.7 & 15.1 & 16.3 & 19.6 & 17.7 & 13.3 & 5.0 & 2.6 & -3.8 \\
\hline 20 & -7.1 & -6.4 & -0.6 & 5.0 & 15.8 & 15.9 & 19.1 & 16.8 & 13.7 & 4.9 & 1.8 & -3.2 \\
\hline 21 & -8.0 & -7.0 & -0.6 & 5.8 & 15.7 & 15.7 & 19.7 & 16.4 & 13.3 & 4.2 & 1.7 & -3.6 \\
\hline 22 & -8.6 & -5.5 & -1.1 & 5.4 & 15.5 & 16.2 & 19.8 & 16.9 & 13.2 & 3.3 & 1.8 & -3.4 \\
\hline 23 & -10.0 & -4.2 & -0.8 & 5.5 & 15.0 & 16.8 & 20.5 & 16.8 & 11.4 & 3.3 & 1.3 & -3.0 \\
\hline 24 & -8.3 & -3.6 & -1.7 & 5.9 & 14.8 & 17.1 & 20.0 & 17.0 & 11.0 & 5.1 & 1.9 & -3.2 \\
\hline 25 & -6.8 & -4.1 & -1.0 & 6.6 & 14.8 & 17.6 & 20.1 & 16.2 & 10.6 & 4.0 & 0.6 & -2.7 \\
\hline 26 & -5.9 & -3.4 & -0.8 & 8.1 & 15.1 & 17.9 & 22.0 & 16.5 & 10.3 & 3.3 & 0.3 & -1.5 \\
\hline 27 & -6.4 & -2.6 & 0.1 & 9.2 & 14.0 & 17.2 & 22.4 & 16.4 & 11.2 & 4.1 & 0.6 & -1.6 \\
\hline 28 & -5.7 & -2.3 & 1.4 & 9.9 & 13.8 & 17.0 & 23.0 & 15.9 & 10.5 & 4.6 & -0.8 & -2.2 \\
\hline 29 & -4.8 & -3.8 & 1.4 & 8.2 & 15.0 & 17.9 & 22.4 & 15.1 & 9.1 & 4.7 & -2.8 & -2.8 \\
\hline 30 & -4.5 & & 1.3 & 8.0 & 14.7 & 18.0 & 21.1 & 14.8 & 9.4 & 3.7 & -3.0 & -2.7 \\
\hline 31 & -6.1 & & 1.1 & & 15.1 & & 21.1 & 14.7 & & 3.3 & & -1.7 \\
\hline
\end{tabular}

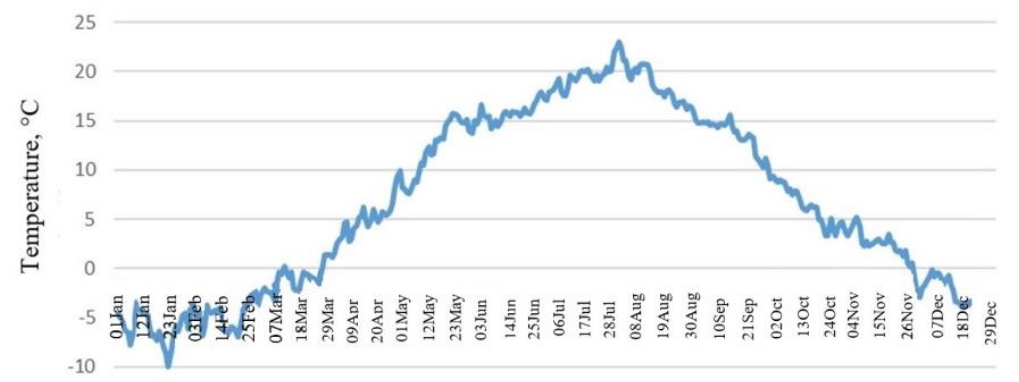

Fig. 1. Typical climatic year's course of daily average temperature

The minimum value is reached in January. The maximum value is reached in late July early August. This is due to the coastal position of the city (the sea is much more inert than air, due to differences in the heat capacity of water and air, respectively, the maximum and minimum temperatures will be shifted relative to more continental cities at the same latitude). [2]

\subsection{Sunshine duration}

Table 2. Duration of sunshine in St. Petersburg (hours)

\begin{tabular}{|l|l|l|l|l|l|l|l|l|l|l|l|l|}
\hline & January & February & March & April & May & June & July & August & Sept. & Oct. & Nov. & Dec. \\
\hline 2009 & 13 & 15 & 90 & 224 & 261 & 194 & 284 & 222 & 139 & 52 & 13 & 4 \\
\hline 2010 & 22 & 32 & 102 & 181 & 216 & 225 & 349 & 248 & 96 & 69 & 2 & 1 \\
\hline 2011 & 8 & 72 & 121 & 188 & 248 & 271 & 276 & 179 & 105 & 47 & 17 & 5 \\
\hline 2012 & 20 & 65 & 106 & 168 & 295 & 247 & 248 & 181 & 106 & 60 & 17 & 10 \\
\hline 2013 & 13 & 21 & 173 & 167 & 259 & 272 & 275 & 244 & 120 & 71 & 20 & 6 \\
\hline 2014 & 27 & 22 & 120 & 261 & 215 & 202 & 346 & 225 & 176 & 63 & 11 & 1 \\
\hline 2015 & 13 & 28 & 132 & 131 & 205 & 272 & 221 & 307 & 102 & 95 & 13 & 10 \\
\hline 2016 & 15 & 14 & 109 & 126 & 299 & 215 & 176 & 167 & 113 & 44 & 6 & 8 \\
\hline 2017 & 17 & 42 & 110 & 137 & 268 & 223 & 196 & 185 & 104 & 18 & 16 & 3 \\
\hline 2018 & 10 & 48 & 124 & 176 & 333 & 241 & 241 & 226 & 148 & 71 & 23 & 1 \\
\hline $\begin{array}{l}\text { Averag } \\
\mathrm{e}\end{array}$ & 15.8 & 35.9 & 118.7 & 175.9 & 259.9 & 236.2 & 261.2 & 218.4 & 120.9 & 59 & 13.8 & 4.9 \\
\hline
\end{tabular}

The maximum value is reached in July. The duration of sunshine in June is reduced compared to May and July. The minimum value is reached in December. Such regularities are explained by the cloud cover throughout the year (the maximum cloud amount is usually observed in June, and the minimum, in contrast, in December) and the duration of daylight hours. 


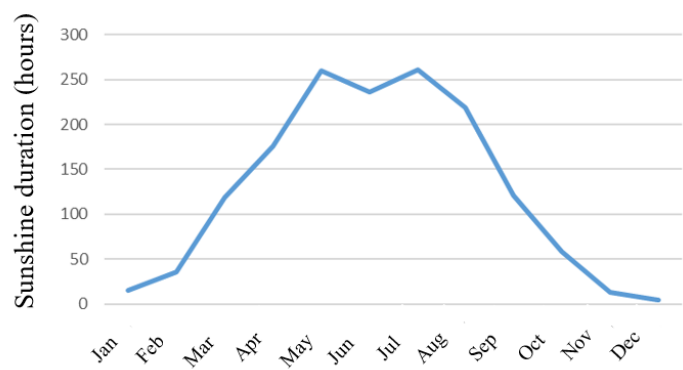

Fig. 2. Change in the duration of sunshine throughout the year

\subsection{Snow depth}

Table 3. Average snow depth $(\mathrm{cm})$

\begin{tabular}{|c|c|c|c|c|c|c|c|c|c|c|c|c|}
\hline & January & February & March & April & May & June & July & August & Sept. & Oct. & Nov. & Dec. \\
\hline 1 & 12 & 17 & 21 & 7 & 0 & 0 & 0 & 0 & 0 & 0 & 1 & 5 \\
\hline 2 & 11 & 18 & 20 & 6 & 0 & 0 & 0 & 0 & 0 & 0 & 0 & 6 \\
\hline 3 & 12 & 17 & 20 & 6 & 0 & 0 & 0 & 0 & 0 & 0 & 0 & 6 \\
\hline 4 & 13 & 18 & 20 & 4 & 0 & 0 & 0 & 0 & 0 & 0 & 0 & 6 \\
\hline 5 & 13 & 20 & 20 & 2 & 0 & 0 & 0 & 0 & 0 & 0 & 0 & 5 \\
\hline 6 & 13 & 20 & 20 & 2 & 0 & 0 & 0 & 0 & 0 & 0 & 0 & 6 \\
\hline 7 & 14 & 21 & 20 & 1 & 0 & 0 & 0 & 0 & 0 & 0 & 1 & 6 \\
\hline 8 & 16 & 20 & 19 & 1 & 0 & 0 & 0 & 0 & 0 & 0 & 2 & 6 \\
\hline 9 & 15 & 20 & 19 & 0 & 0 & 0 & 0 & 0 & 0 & 0 & 3 & 6 \\
\hline 10 & 16 & 20 & 19 & 0 & 0 & 0 & 0 & 0 & 0 & 0 & 3 & 8 \\
\hline 11 & 15 & 20 & 19 & 0 & 0 & 0 & 0 & 0 & 0 & 0 & 3 & 10 \\
\hline 12 & 15 & 19 & 19 & 0 & 0 & 0 & 0 & 0 & 0 & 0 & 3 & 10 \\
\hline 13 & 15 & 19 & 19 & 0 & 0 & 0 & 0 & 0 & 0 & 0 & 3 & 9 \\
\hline 14 & 15 & 19 & 18 & 1 & 0 & 0 & 0 & 0 & 0 & 0 & 3 & 8 \\
\hline 15 & 16 & 21 & 18 & 1 & 0 & 0 & 0 & 0 & 0 & 0 & 2 & 9 \\
\hline 16 & 17 & 21 & 19 & 0 & 0 & 0 & 0 & 0 & 0 & 0 & 2 & 8 \\
\hline 17 & 16 & 21 & 18 & 0 & 0 & 0 & 0 & 0 & 0 & 0 & 2 & 8 \\
\hline 18 & 17 & 21 & 18 & 0 & 0 & 0 & 0 & 0 & 0 & 0 & 1 & 8 \\
\hline 19 & 17 & 21 & 17 & 0 & 0 & 0 & 0 & 0 & 0 & 0 & 0 & 8 \\
\hline 20 & 17 & 21 & 18 & 0 & 0 & 0 & 0 & 0 & 0 & 0 & 0 & 7 \\
\hline 21 & 17 & 20 & 17 & 0 & 0 & 0 & 0 & 0 & 0 & 0 & 0 & 8 \\
\hline 22 & 18 & 21 & 17 & 0 & 0 & 0 & 0 & 0 & 0 & 0 & 0 & 9 \\
\hline 23 & 18 & 23 & 16 & 0 & 0 & 0 & 0 & 0 & 0 & 0 & 0 & 10 \\
\hline 24 & 19 & 24 & 15 & 0 & 0 & 0 & 0 & 0 & 0 & 0 & 1 & 12 \\
\hline 25 & 19 & 23 & 15 & 0 & 0 & 0 & 0 & 0 & 0 & 0 & 2 & 13 \\
\hline 26 & 19 & 22 & 14 & 0 & 0 & 0 & 0 & 0 & 0 & 0 & 3 & 14 \\
\hline 27 & 19 & 23 & 14 & 0 & 0 & 0 & 0 & 0 & 0 & 0 & 3 & 14 \\
\hline 28 & 17 & 22 & 13 & 0 & 0 & 0 & 0 & 0 & 0 & 0 & 3 & 13 \\
\hline 29 & 17 & 16 & 11 & 0 & 0 & 0 & 0 & 0 & 0 & 0 & 3 & 13 \\
\hline 30 & 18 & & 10 & 0 & 0 & 0 & 0 & 0 & 0 & 0 & 4 & 12 \\
\hline 31 & 17 & & 9 & & 0 & 0 & 0 & 0 & 0 & 1 & & 13 \\
\hline
\end{tabular}

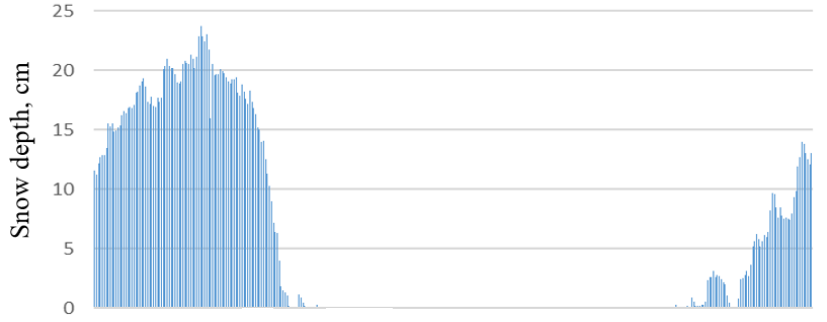

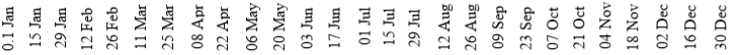

Fig. 3. Average snow depth $(\mathrm{cm})$

The maximum snow depths are reached around mid-February, as snow manages to accumulate during the winter. A sharp decrease in the average snow depth in March is explained by frequent thaws. In autumn and in December, the snow cover is still unstable. 
This is represented by large amplitudes of average snow depth in the histogram.

\subsection{Wind speed and direction}

Table 4. Average wind speeds $(\mathrm{m} / \mathrm{s})$

\begin{tabular}{|c|c|c|c|c|c|c|c|c|c|c|c|c|}
\hline & $\begin{array}{c}\text { Januar } \\
\mathrm{y}\end{array}$ & $\begin{array}{c}\text { Februar } \\
\mathrm{y}\end{array}$ & $\begin{array}{c}\text { Marc } \\
\mathrm{h}\end{array}$ & $\begin{array}{c}\text { Apri } \\
1\end{array}$ & $\begin{array}{c}\mathrm{Ma} \\
\mathrm{y}\end{array}$ & $\begin{array}{c}\text { Jun } \\
\mathrm{e}\end{array}$ & $\begin{array}{c}\text { Jul } \\
\mathrm{y}\end{array}$ & $\begin{array}{c}\text { Augus } \\
t\end{array}$ & Sept. & Oct & Nov. & Dec. \\
\hline 1 & 2.1 & 2.3 & 1.9 & 2.0 & 2.1 & 1.9 & 1.7 & 1.9 & 1.6 & 2.0 & 2.3 & 2.1 \\
\hline 2 & 2.3 & 2.6 & 2.0 & 2.1 & 2.2 & 1.9 & 1.7 & 1.7 & 1.5 & 1.9 & 2.2 & 2.5 \\
\hline 3 & 2.1 & 1.9 & 2.1 & 2.0 & 2.2 & 2.0 & 1.8 & 1.6 & 1.6 & 1.6 & 2.0 & 2.8 \\
\hline 4 & 1.9 & 1.8 & 2.0 & 1.9 & 1.7 & 2.2 & 1.6 & 1.8 & 1.7 & 2.0 & 2.4 & 2.1 \\
\hline 5 & 2.1 & 1.7 & 1.8 & 2.1 & 1.8 & 2.1 & 1.9 & 1.5 & 1.5 & 2.5 & 2.3 & 2.9 \\
\hline 6 & 2.3 & 2.0 & 1.9 & 2.4 & 2.0 & 1.5 & 1.5 & 1.8 & 1.5 & 2.1 & 1.9 & 3.0 \\
\hline 7 & 2.3 & 1.8 & 2.2 & 1.7 & 1.8 & 1.8 & 1.5 & 1.8 & 1.3 & 2.2 & 2.3 & 2.6 \\
\hline 8 & 1.9 & 2.3 & 2.4 & 1.9 & 1.7 & 1.8 & 1.6 & 2.0 & 1.5 & 2.1 & 2.1 & 2.3 \\
\hline 9 & 1.8 & 1.8 & 2.3 & 2.1 & 1.9 & 1.6 & 1.8 & 2.1 & 1.4 & 2.0 & 2.0 & 2.4 \\
\hline 10 & 2.0 & 1.5 & 2.1 & 2.3 & 1.7 & 1.6 & 1.5 & 2.1 & 1.1 & 2.0 & 2.2 & 2.5 \\
\hline 11 & 2.6 & 1.6 & 2.2 & 1.9 & 1.7 & 2.0 & 1.4 & 1.7 & 1.2 & 1.7 & 2.1 & 2.2 \\
\hline 12 & 2.5 & 2.0 & 1.8 & 1.7 & 1.9 & 1.9 & 1.6 & 1.9 & 1.8 & 1.6 & 2.2 & 2.3 \\
\hline 13 & 2.7 & 2.0 & 1.9 & 1.9 & 2.1 & 1.9 & 1.6 & 2.0 & 1.8 & 1.6 & 2.5 & 3.0 \\
\hline 14 & 2.0 & 1.8 & 2.2 & 1.8 & 2.2 & 1.9 & 1.8 & 2.0 & 1.9 & 1.7 & 2.0 & 2.2 \\
\hline 15 & 1.4 & 1.6 & 2.0 & 2.4 & 1.9 & 2.1 & 1.7 & 1.9 & 2.2 & 1.7 & 2.2 & 2.5 \\
\hline 16 & 1.8 & 1.5 & 2.3 & 1.7 & 1.6 & 2.1 & 1.9 & 1.7 & 2.0 & 1.8 & 2.4 & 2.2 \\
\hline 17 & 1.9 & 1.7 & 2.0 & 2.3 & 1.5 & 2.4 & 2.1 & 1.7 & 1.9 & 1.9 & 2.7 & 2.2 \\
\hline 18 & 1.9 & 1.9 & 1.8 & 2.8 & 1.7 & 2.8 & 1.6 & 1.7 & 1.9 & 2.5 & 2.3 & 2.5 \\
\hline 19 & 1.8 & 2.1 & 1.9 & 2.3 & 1.6 & 2.4 & 2.1 & 2.0 & 2.2 & 2.6 & 2.3 & 2.3 \\
\hline 20 & 1.7 & 2.0 & 2.2 & 2.1 & 1.5 & 2.3 & 1.8 & 1.5 & 1.6 & 1.6 & 2.2 & 2.7 \\
\hline 21 & 1.5 & 2.0 & 2.4 & 2.1 & 1.5 & 2.0 & 1.6 & 1.5 & 1.5 & 1.7 & 2.1 & 2.3 \\
\hline 22 & 1.5 & 2.2 & 2.3 & 1.4 & 1.7 & 1.7 & 1.7 & 1.7 & 2.1 & 2.0 & 2.2 & 2.3 \\
\hline 23 & 1.8 & 2.3 & 2.4 & 2.0 & 1.8 & 1.6 & 1.7 & 1.7 & 2.1 & 2.1 & 1.8 & 2.5 \\
\hline 24 & 1.8 & 2.6 & 2.2 & 2.2 & 1.7 & 1.6 & 1.7 & 1.6 & 1.9 & 2.1 & 2.5 & 2.6 \\
\hline 25 & 2.2 & 1.8 & 2.0 & 2.2 & 1.6 & 1.6 & 1.6 & 1.5 & 1.9 & 2.3 & 2.0 & 2.6 \\
\hline 26 & 2.2 & 1.8 & 1.9 & 2.0 & 1.5 & 1.3 & 1.4 & 1.5 & 1.7 & 2.0 & 2.4 & 3.0 \\
\hline 27 & 1.8 & 1.7 & 1.9 & 1.9 & 1.7 & 1.9 & 1.3 & 2.0 & 2.1 & 2.1 & 2.9 & 2.4 \\
\hline 28 & 2.2 & 1.8 & 2.3 & 1.9 & 1.5 & 2.1 & 1.2 & 1.5 & 2.1 & 2.4 & 3.0 & 2.1 \\
\hline 29 & 2.4 & 1.6 & 1.9 & 2.1 & 1.5 & 1.3 & 1.5 & 1.7 & 2.0 & 2.8 & 2.3 & 2.3 \\
\hline 30 & 2.5 & & 1.9 & 2.1 & 1.9 & 1.5 & 1.5 & 1.6 & 2.5 & 2.2 & 2.2 & 2.4 \\
\hline 31 & 2.1 & & 1.9 & & 1.5 & & 1.7 & 1.5 & & 2.4 & & 2.0 \\
\hline Average & 2.0 & 1.9 & 2.1 & 2.0 & 1.7 & 1.9 & 1.6 & 1.7 & 1.8 & 2.0 & 2.3 & 2.4 \\
\hline
\end{tabular}

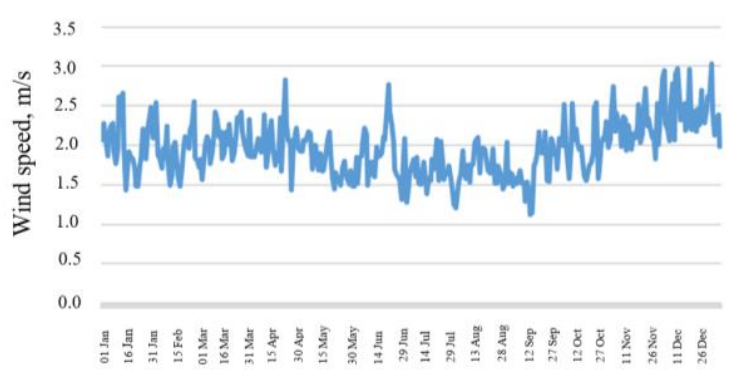

Fig. 4. Average wind speed (annual course)

Wind speeds reach their maximum values in December, which is explained by active cyclonic activity in the winter period. Minimum speeds are observed in the summer (especially in July), cyclonic activity is weakened during this period.

\subsection{Wind direction}

It can be noted that the prevailing winds in St. Petersburg are of the western directions (western, southwest), both regarding the whole year and also for particular months, which is due to the Atlantic effect. Also, northern (mainly in late summer and early autumn) and southeastern winds (mainly in winter) are often observed. 


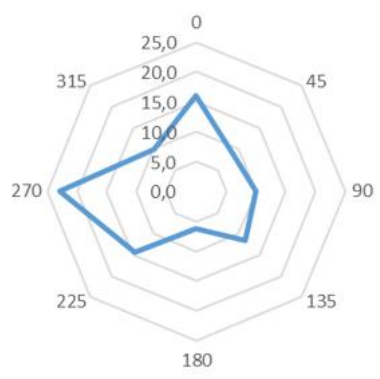

Fig. 5. Wind rose in St. Petersburg (2009-2018)

Table 5. Relative air humidity (\%)

\begin{tabular}{|c|c|c|c|c|c|c|c|c|c|c|c|c|}
\hline & January & February & March & April & May & June & July & August & Sept. & Oct. & Nov. & Dec. \\
\hline 1 & 86 & 83 & 83 & 71 & 68 & 55 & 74 & 71 & 77 & 81 & 85 & 85 \\
\hline 2 & 86 & 82 & 82 & 77 & 69 & 68 & 70 & 73 & 80 & 78 & 86 & 87 \\
\hline 3 & 86 & 86 & 78 & 78 & 58 & 68 & 65 & 68 & 80 & 80 & 89 & 85 \\
\hline 4 & 85 & 85 & 80 & 66 & 62 & 58 & 73 & 72 & 79 & 81 & 87 & 87 \\
\hline 5 & 83 & 85 & 78 & 69 & 66 & 61 & 71 & 72 & 78 & 76 & 83 & 88 \\
\hline 6 & 85 & 83 & 75 & 71 & 61 & 58 & 67 & 69 & 78 & 77 & 87 & 88 \\
\hline 7 & 83 & 85 & 75 & 75 & 58 & 60 & 71 & 70 & 85 & 77 & 90 & 85 \\
\hline 8 & 85 & 86 & 78 & 70 & 62 & 63 & 72 & 70 & 80 & 80 & 89 & 85 \\
\hline 9 & 89 & 85 & 73 & 63 & 59 & 63 & 71 & 68 & 77 & 82 & 84 & 86 \\
\hline 10 & 90 & 87 & 81 & 60 & 63 & 66 & 68 & 69 & 80 & 82 & 87 & 86 \\
\hline 11 & 85 & 86 & 85 & 62 & 69 & 69 & 67 & 71 & 81 & 82 & 87 & 89 \\
\hline 12 & 88 & 85 & 81 & 65 & 62 & 75 & 67 & 72 & 81 & 85 & 85 & 87 \\
\hline 13 & 90 & 84 & 79 & 67 & 57 & 70 & 68 & 74 & 79 & 86 & 85 & 83 \\
\hline 14 & 88 & 81 & 74 & 73 & 54 & 65 & 66 & 75 & 78 & 83 & 86 & 81 \\
\hline 15 & 87 & 83 & 72 & 67 & 52 & 64 & 70 & 75 & 77 & 84 & 87 & 84 \\
\hline 16 & 84 & 83 & 69 & 65 & 58 & 68 & 72 & 74 & 80 & 79 & 87 & 86 \\
\hline 17 & 85 & 82 & 72 & 69 & 63 & 67 & 72 & 71 & 80 & 79 & 85 & 84 \\
\hline 18 & 85 & 84 & 66 & 62 & 64 & 67 & 72 & 73 & 78 & 78 & 87 & 85 \\
\hline 19 & 86 & 84 & 71 & 64 & 64 & 66 & 69 & 74 & 78 & 77 & 87 & 85 \\
\hline 20 & 83 & 83 & 74 & 66 & 63 & 69 & 75 & 76 & 81 & 81 & 85 & 86 \\
\hline 21 & 84 & 81 & 71 & 70 & 62 & 73 & 73 & 74 & 81 & 80 & 87 & 86 \\
\hline 22 & 86 & 83 & 72 & 71 & 61 & 67 & 75 & 73 & 81 & 78 & 86 & 85 \\
\hline 23 & 86 & 84 & 74 & 69 & 62 & 64 & 75 & 77 & 83 & 81 & 88 & 86 \\
\hline 24 & 85 & 82 & 72 & 69 & 60 & 68 & 75 & 76 & 78 & 83 & 87 & 83 \\
\hline 25 & 86 & 83 & 69 & 71 & 64 & 71 & 73 & 78 & 77 & 81 & 89 & 85 \\
\hline 26 & 86 & 84 & 66 & 69 & 68 & 70 & 68 & 78 & 83 & 81 & 87 & 84 \\
\hline 27 & 86 & 83 & 68 & 67 & 65 & 71 & 67 & 75 & 79 & 84 & 87 & 85 \\
\hline 28 & 85 & 83 & 71 & 64 & 68 & 73 & 64 & 75 & 80 & 85 & 82 & 84 \\
\hline 29 & 85 & 88 & 71 & 71 & 64 & 65 & 72 & 78 & 79 & 81 & 82 & 87 \\
\hline 30 & 82 & & 67 & 69 & 64 & 68 & 73 & 79 & 82 & 83 & 85 & 86 \\
\hline 31 & 82 & & 67 & & 60 & & 70 & 75 & & 85 & & 86 \\
\hline
\end{tabular}

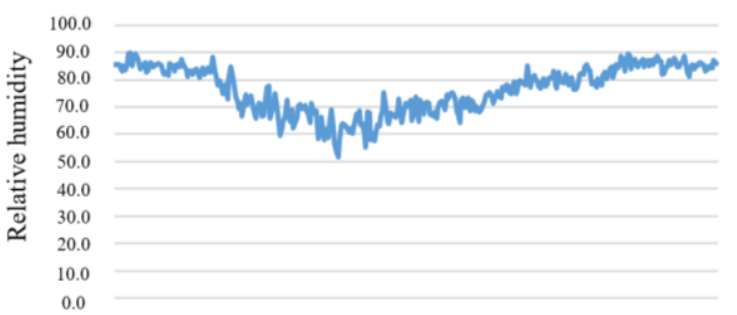

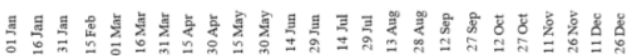

Fig. 6. Relative air humidity (\%)

The annual course of relative air humidity is the opposite of the temperature one. Maximum values are reached in winter and late autumn, air temperature decreases and western winds prevail (see Figure 7), bringing humid air from the sea.

It can be seen that in spring and summer the fluctuation amplitude of the relative humidity is greatest. This is due to the fact that the air temperature is constantly quite high during this period (at least much higher than in winter). Thus, there may be more water vapor in the air, 
therefore the relative humidity is less than in winter, and its values fluctuate due to the humid air influx from the Atlantic. In winter, the air temperature is low, so humidity in the air is kept worse, and the influx from the Atlantic side does not affect the relative humidity (since it is high already). [6]

\subsection{The heating period duration in St. Petersburg.}

Table 6. Heating period duration (days)

\begin{tabular}{|c|c|c|c|}
\hline Period & Start & Finish & Duration (days) \\
\hline $2009-2010$ & 01.10 .2009 & 07.05 .2010 & 218 \\
\hline $2010-2011$ & 10.10 .2010 & 07.05 .2011 & 209 \\
\hline $2011-2012$ & 11.10 .2011 & 04.05 .2012 & 206 \\
\hline $2012-2013$ & 10.10 .2012 & 03.05 .2013 & 226 \\
\hline $2013-2014$ & 25.09 .2013 & 09.05 .2014 & 229 \\
\hline $2014-2015$ & 02.10 .2014 & 19.05 .2015 & 212 \\
\hline $2015-2016$ & 07.10 .2015 & 06.05 .2016 & 241 \\
\hline $2016-2017$ & 20.09 .2016 & 19.05 .2017 & 218 \\
\hline $2017-2018$ & 04.10 .2017 & 10.05 .2018 & 018 \\
\hline
\end{tabular}

The heating period begins after a stable average daily temperature of $8^{\circ} \mathrm{C}$ settled (usually, if the temperature does not exceed $8^{\circ} \mathrm{C}$ during five days, the heating period starts).

\subsection{The number of degree-hours during the heating period}

Table 7. Degree-hours during the heating period

\begin{tabular}{|c|c|c|c|c|c|}
\hline Period & $\begin{array}{c}\text { Avg. heating period } \\
\text { temperature }\end{array}$ & $\begin{array}{c}\text { Basic } \\
\text { temperature }\end{array}$ & $\begin{array}{c}\text { Duration } \\
\text { (days) }\end{array}$ & $\begin{array}{c}\text { The number of } \\
\text { degree-days }\end{array}$ & $\begin{array}{c}\text { The number of } \\
\text { degree-hours }\end{array}$ \\
\hline $2009-2010$ & -1.70 & -2 & 218 & 66 & 1574 \\
\hline $2010-2011$ & -2.34 & -2 & 209 & 71 & 1698 \\
\hline $2011-2012$ & -0.02 & -2 & 206 & -409 & -9804 \\
\hline $2012-2013$ & -1.78 & -2 & 205 & -44 & -1060 \\
\hline $2013-2014$ & 2.25 & -2 & 226 & -959 & -23026 \\
\hline $2014-2015$ & 2.10 & -2 & 229 & -939 & -22534 \\
\hline $2015-2016$ & 1.05 & -2 & 212 & -646 & -15505 \\
\hline $2016-2017$ & 0.98 & -2 & 241 & -717 & -17216 \\
\hline $2017-2018$ & 0.34 & -2 & 218 & -510 & -12230 \\
\hline
\end{tabular}

It is noticeable that the number of degree-days in the heating season depends mainly on the average period duration, and not on the average outdoor temperature.

Table 8. Crossings through $-2^{\circ} \mathrm{C}$.

\begin{tabular}{|c|c|}
\hline Heating period & Number of crossing through $-2^{\circ} \mathrm{C}$ \\
\hline $2009-2010$ & 8 \\
\hline $2010-2011$ & 14 \\
\hline $2011-2012$ & 14 \\
\hline $2012-2013$ & 16 \\
\hline $2013-2014$ & 14 \\
\hline $2014-2015$ & 20 \\
\hline $2015-2016$ & 10 \\
\hline $2016-2017$ & 30 \\
\hline $2017-2018$ & 16 \\
\hline
\end{tabular}




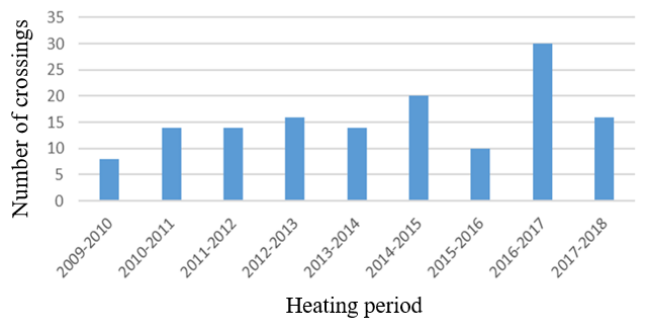

Fig. 7. Crossings through $-2^{\circ} \mathrm{C}$ throughout the heating periods in St. Petersburg.

The greatest number of $-2^{\circ} \mathrm{C}$ crossings (30) was observed during the heating season 2016 2017. The minimum number of such crossings (8) was observed during the heating season 2009-2010, and a low number (10) was observed during the heating season 2015-2016.

Table 9. Periods with temperatures exceeding $-2^{\circ} \mathrm{C}$.

\begin{tabular}{|c|c|c|c|}
\hline Heating season & Average duration & $\begin{array}{c}\text { Total number of periods } \\
\text { during the season }\end{array}$ & $\begin{array}{c}\text { Average number of } \\
\text { degree-days per period }\end{array}$ \\
\hline $2009-2010$ & 24 & 5 & 147 \\
\hline $2010-2011$ & 14 & 7 & 83 \\
\hline $2011-2012$ & 18 & 8 & 96 \\
\hline $2012-2013$ & 10 & 9 & 60 \\
\hline $2013-2014$ & 22 & 8 & 144 \\
\hline $2014-2015$ & 16 & 11 & 95 \\
\hline $2015-2016$ & 27 & 6 & 159 \\
\hline $2016-2017$ & 10 & 16 & 57 \\
\hline $2017-2018$ & 16 & 9 & 90 \\
\hline
\end{tabular}
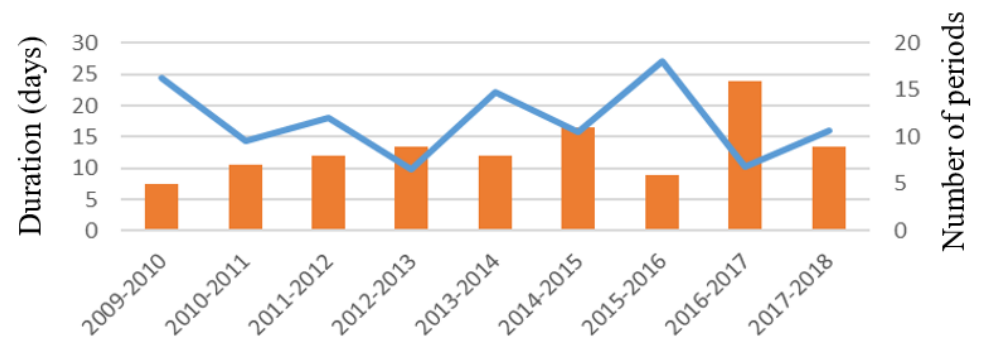

Heating season

Number of periods $\longrightarrow$ Average duration of a period

Fig. 8. The number and average duration of periods of the heating season with a temperature exceeding $-2^{\circ} \mathrm{C}$.

In general, it is noticeable that changes in the number of periods with a temperature exceeding $-2^{\circ} \mathrm{C}$ are inversely proportional to changes in the average duration of such periods.

The maximum number of such periods (16) was observed during the heating season 20162017, however, their average duration (10 days) was one of the lowest for 2009-2018.

On the contrary, the minimum number of periods with a temperature exceeding $-2^{\circ} \mathrm{C}$, which is 5 periods, was observed during the heating season 2009-2010. The average duration of periods during the heating season 2009-2010 is 24 days.

Table 10. Periods with temperature not exceeding $-2^{\circ} \mathrm{C}$.

\begin{tabular}{|c|c|c|c|}
\hline Heating season & $\begin{array}{c}\text { Average } \\
\text { duration }\end{array}$ & $\begin{array}{c}\text { Total number of periods } \\
\text { during the season }\end{array}$ & $\begin{array}{c}\text { Average number of degree- } \\
\text { days per period }\end{array}$ \\
\hline $2009-2010$ & 22 & 4 & -170 \\
\hline
\end{tabular}




\begin{tabular}{|c|c|c|c|}
\hline $2010-2011$ & 11 & 8 & -82 \\
\hline $2011-2012$ & 7 & 7 & -52 \\
\hline $2012-2013$ & 10 & 9 & -54 \\
\hline $2013-2014$ & 6 & 5 & -42 \\
\hline $2014-2015$ & 3 & 9 & -13 \\
\hline $2015-2016$ & 9 & 4 & -80 \\
\hline $2016-2017$ & 4 & 12 & -16 \\
\hline $2017-2018$ & 9 & 6 & -50 \\
\hline
\end{tabular}

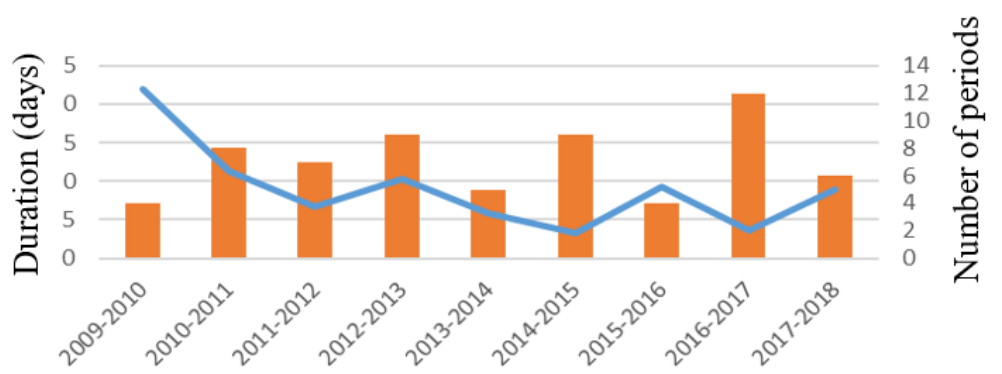

Heating season

Number of periods - Average duration of a period

Fig. 9. The number and average duration of periods of the heating season with a temperature not exceeding $-2^{\circ} \mathrm{C}$.

According to the Figure 10, the changes in the number of periods with a temperature not exceeding $-2^{\circ} \mathrm{C}$ are inversely proportional to changes in the average duration of such periods. The maximum number of periods, as in the previous case, is observed during the heating season 2016-2017 (according to it Table 7, it is the longest of all along with the 20092010season). The average duration of such periods is small, 4 days at average. The longest average period duration (22 days) was observed during the heating season 2009-2010. In the same season, the number of periods was minimal (4). [6]

Table 11. Periods with an average daily relative humidity above $60 \%$ at a temperature between $+5^{\circ} \mathrm{C}$ and $-3^{\circ} \mathrm{C}$.

\begin{tabular}{|c|c|c|}
\hline Heating season & Average period duration & Total number of periods \\
\hline $2009-2010$ & 6 & 11 \\
\hline $2010-2011$ & 4 & 15 \\
\hline $2011-2012$ & 7 & 14 \\
\hline $2012-2013$ & 5 & 13 \\
\hline $2013-2014$ & 6 & 14 \\
\hline $2014-2015$ & 7 & 17 \\
\hline $2015-2016$ & 6 & 16 \\
\hline $2016-2017$ & 6 & 21 \\
\hline $2017-2018$ & 10 & 9 \\
\hline
\end{tabular}

The greatest number of periods with an average daily relative humidity above $60 \%$ was observed during the heating season 2016-2017.

The smallest amount (9) was observed in the 2017-2018 season, while the greatest duration of the periods was observed (10 days on average). The shortest duration was observed during the heating season of 2010-2011. On average, the average daily relative humidity was above $60 \%$ at temperatures between $+5^{\circ} \mathrm{C}$ and $-3^{\circ} \mathrm{C}$ lasted 4 days. 


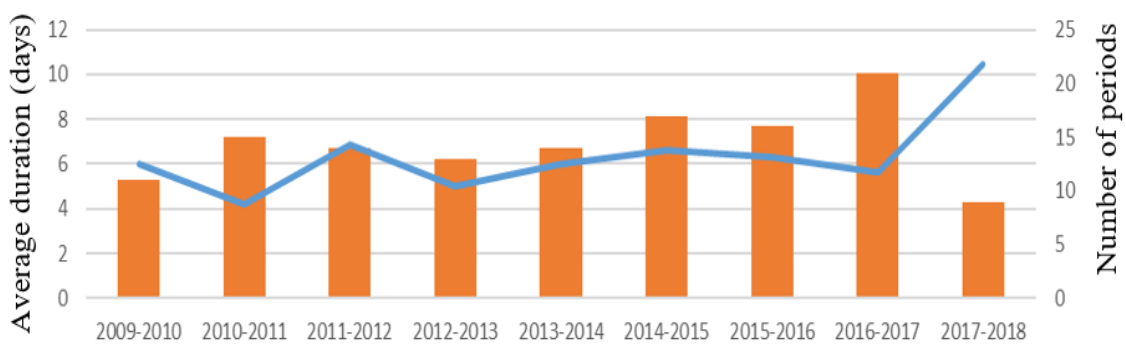

Heating season

Number of periods - Average duration of a period

Fig. 10. The number and average duration of periods with an average daily relative humidity above $60 \%$ at temperatures between $+5^{\circ} \mathrm{C}$ and $-3^{\circ} \mathrm{C}$ during the heating period.

\section{Typical climatic year's annual course of the average daily outdoor temperature in Moscow}

In order to represent the climatic state of Moscow over the past 10 years, illustrative and tabular data on meteorological parameters are exposed. The RIHMI-WDC data for 20092018 was used for calculations, such as data on the air temperature timing, relative humidity, wind direction and speed, data on the snow depth per day and the sunshine duration per month. [6-7]

\subsection{Daily average air temperature}

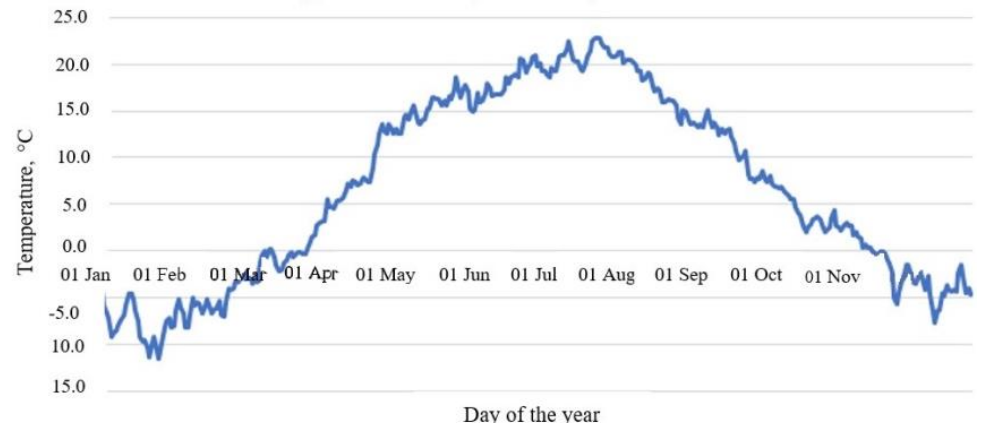

Fig. 11. Typical climatic year's temperature course

Table 12. Typical climatic year's temperature course

\begin{tabular}{|c|c|c|c|c|c|c|c|c|c|c|c|c|}
\hline Day/month & January & February & March & April & May & June & July & August & Sept. & Oct. & Nov. & Dec. \\
\hline 01 & -3.6 & -8.0 & -3.0 & 1.7 & 12.6 & 16.5 & 20.8 & 21.8 & 13.6 & 7.8 & 2.2 & -4.5 \\
\hline 02 & -4.3 & -6.4 & -2.9 & 2.8 & 13.5 & 17.5 & 20.9 & 21.2 & 15.2 & 7.3 & 2.5 & -3.1 \\
\hline 03 & -5.9 & -5.2 & -3.0 & 3.0 & 13.0 & 17.8 & 19.8 & 20.8 & 14.9 & 7.8 & 3.6 & -3.0 \\
\hline 04 & -6.7 & -6.0 & -2.3 & 3.1 & 12.6 & 17.1 & 20.1 & 20.8 & 13.9 & 7.8 & 4.4 & -1.4 \\
\hline 05 & -7.2 & -6.7 & -2.8 & 3.2 & 13.2 & 15.4 & 19.3 & 21.0 & 13.6 & 8.5 & 2.8 & -1.5 \\
\hline 06 & -9.1 & -8.2 & -3.5 & 5.5 & 12.6 & 14.9 & 19.3 & 21.4 & 13.8 & 7.5 & 2.5 & -2.6 \\
\hline 07 & -8.8 & -8.2 & -3.0 & 4.8 & 12.6 & 15.1 & 19.0 & 21.3 & 13.6 & 7.4 & 2.2 & -3.3 \\
\hline 08 & -8.5 & -6.8 & -3.3 & 4.7 & 14.3 & 16.9 & 18.5 & 20.2 & 13.3 & 8.0 & 2.6 & -3.5 \\
\hline 09 & -8.0 & -5.0 & -1.2 & 4.5 & 14.5 & 16.0 & 19.6 & 20.5 & 13.5 & 7.3 & 3.0 & -3.1 \\
\hline 10 & -7.3 & -5.9 & -0.6 & 5.4 & 14.1 & 16.1 & 19.3 & 20.5 & 13.3 & 6.9 & 2.7 & -2.4 \\
\hline 11 & -6.9 & -5.5 & 0.0 & 5.3 & 14.7 & 17.0 & 19.2 & 20.5 & 14.1 & 7.0 & 2.8 & -2.9 \\
\hline 12 & -5.8 & -5.7 & -0.6 & 5.6 & 15.7 & 18.0 & 20.9 & 20.4 & 15.1 & 6.7 & 1.6 & -4.2 \\
\hline 13 & -4.6 & -6.7 & 0.1 & 5.8 & 14.9 & 17.5 & 21.0 & 19.9 & 14.3 & 6.9 & 2.1 & -2.7 \\
\hline
\end{tabular}




\begin{tabular}{|l|c|c|c|c|c|c|c|c|c|c|c|c|}
\hline 14 & -4.2 & -5.8 & 0.1 & 6.5 & 13.7 & 16.6 & 21.0 & 19.3 & 13.3 & 6.4 & 1.5 & -4.6 \\
\hline 15 & -5.1 & -5.2 & -0.6 & 7.3 & 13.6 & 16.7 & 21.7 & 19.2 & 13.7 & 6.2 & 1.3 & -6.5 \\
\hline 16 & -6.3 & -6.3 & -1.5 & 6.9 & 14.2 & 16.8 & 22.5 & 18.3 & 13.2 & 5.8 & 0.3 & -7.7 \\
\hline 17 & -7.5 & -6.6 & -2.1 & 7.6 & 14.1 & 16.8 & 21.2 & 18.4 & 12.5 & 5.6 & 0.7 & -6.3 \\
\hline 18 & -9.2 & -6.3 & -2.1 & 7.3 & 15.3 & 16.7 & 20.4 & 19.1 & 13.0 & 5.5 & 0.4 & -6.3 \\
\hline 19 & -9.7 & -6.1 & -1.4 & 7.0 & 15.3 & 17.3 & 20.3 & 18.9 & 12.6 & 4.7 & 0.4 & -4.5 \\
\hline 20 & -9.6 & -5.4 & -0.9 & 7.1 & 16.4 & 18.7 & 20.3 & 17.7 & 13.0 & 4.1 & 0.1 & -4.9 \\
\hline 21 & -10.3 & -6.9 & -0.4 & 7.9 & 16.4 & 18.0 & 19.5 & 17.2 & 13.1 & 3.8 & -0.5 & -3.7 \\
\hline 22 & -11.4 & -7.1 & -0.2 & 7.8 & 16.3 & 18.5 & 19.3 & 17.5 & 12.2 & 2.7 & -0.4 & -4.2 \\
\hline 23 & -9.8 & -5.5 & -0.6 & 7.3 & 16.2 & 18.8 & 20.1 & 17.4 & 11.6 & 2.0 & -1.4 & -4.4 \\
\hline 24 & -9.3 & -4.1 & -0.3 & 7.5 & 15.7 & 19.0 & 20.7 & 16.0 & 10.8 & 2.6 & -0.7 & -4.1 \\
\hline 25 & -10.7 & -4.1 & -0.2 & 8.9 & 16.1 & 18.7 & 21.4 & 16.0 & 9.7 & 2.9 & -0.1 & -4.4 \\
\hline 26 & -11.6 & -4.1 & -0.1 & 10.4 & 15.6 & 20.6 & 22.6 & 16.1 & 10.0 & 3.3 & -1.0 & -2.4 \\
\hline 27 & -9.9 & -3.3 & -0.4 & 11.4 & 16.6 & 20.4 & 22.8 & 16.3 & 10.2 & 3.5 & -1.3 & -1.5 \\
\hline 28 & -8.1 & -3.3 & -0.3 & 12.6 & 16.2 & 19.1 & 22.8 & 16.1 & 10.8 & 3.8 & -2.3 & -2.7 \\
\hline 29 & -7.5 & & 0.2 & 13.6 & 17.4 & 19.6 & 22.8 & 16.1 & 8.3 & 3.3 & -5.0 & -4.5 \\
\hline 30 & -7.3 & & 1.1 & 12.9 & 18.6 & 20.1 & 22.4 & 15.6 & 7.8 & 2.9 & -5.7 & -4.1 \\
\hline 31 & -8.2 & & 1.5 & & 17.1 & & 21.8 & 14.3 & & 2.1 & & -4.6 \\
\hline
\end{tabular}

\subsection{Sunshine duration}

Table 13. Sunshine duration of in Moscow (hours)

\begin{tabular}{|c|c|c|c|c|c|c|c|c|c|c|c|c|c|}
\hline $\begin{array}{c}\text { Year } \backslash \\
\text { month }\end{array}$ & Jan. & Febr. & March & April & May & June & July & August & Sept. & Oct. & Nov. & Dec. & \\
\hline 2010 & 75.3 & 61.7 & 160.8 & 230.1 & 255.7 & 286.1 & 396 & 193.4 & 171.6 & 111.7 & 14.9 & 25.9 & 1983.6 \\
\hline 2011 & 46.3 & 61.7 & 150.9 & 199.4 & 292.6 & 340.1 & 338.2 & 294.8 & 131.1 & 58.4 & 39.7 & 10.5 & 1964 \\
\hline 2012 & 54 & 54.7 & 119.7 & 175.1 & 285 & 286.9 & 312.4 & 225.6 & 163.2 & 39.6 & 16.5 & 44.3 & 1777 \\
\hline 2013 & 31.7 & 64.2 & 136.2 & 204.1 & 255.2 & 337.7 & 235.5 & 266.2 & 60.5 & 78.7 & 23.7 & 13.5 & 1707 \\
\hline 2014 & 73.2 & 48.1 & 168.5 & 258.4 & 307.9 & 271.7 & 411.2 & 275.1 & 203.8 & 91 & 44.7 & 14.2 & 2168 \\
\hline 2015 & 27.6 & 60.3 & 163.3 & 169.7 & 259.7 & 291.7 & 304 & 324.9 & 157.7 & 95.9 & 27.4 & 17.2 & 1899 \\
\hline 2016 & 29 & 49.4 & 139.8 & 176.6 & 278.8 & 298.8 & 289.2 & 295.8 & 91.1 & 37 & 28 & 22.9 & 1736 \\
\hline 2017 & 36.1 & 54.5 & 136.7 & 165.2 & 267.9 & 235.6 & 257.6 & 282.4 & 171.6 & 32 & 21.1 & 0.1 & 1661 \\
\hline Average & 46.7 & 56.8 & 147.0 & 197.3 & 275.4 & 293.6 & 318.0 & 269.8 & 143.8 & 68.0 & 27.0 & 18.6 & 1862.0 \\
\hline $\begin{array}{l}\text { Poss. } \\
\text { Max. }\end{array}$ & 190 & 237 & 333 & 351 & 462 & 362 & 396 & 448 & 505 & 178 & 132 & 42 & 3818 \\
\hline
\end{tabular}

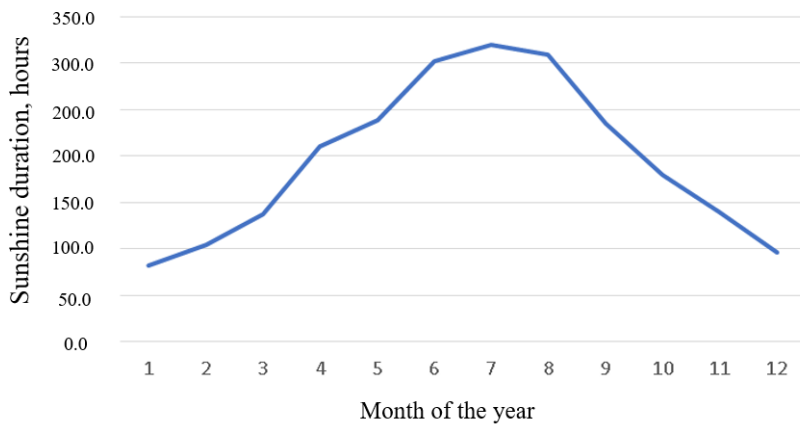

Fig. 12. Annual course of the sunshine duration in Moscow (hours)

\subsection{Snow depth}

Table 14. Average snow depth $(\mathrm{cm})$

\begin{tabular}{|c|c|c|c|c|c|c|c|c|c|c|c|c|}
\hline $\begin{array}{c}\text { Day } \\
\text { Month }\end{array}$ & Jan. & Febr. & March & April & May & June & July & August & Sept. & Oct. & Nov. & Dec. \\
\hline 01 & 14.3 & 30.3 & 34 & 21.9 & 0 & 0 & 0 & 0 & 0 & 0 & 1.2 & 5.1 \\
\hline 02 & 13.7 & 30 & 36 & 19 & 0 & 0 & 0 & 0 & 0 & 0 & 0.9 & 5.6 \\
\hline 03 & 13.9 & 29.9 & 34.5 & 16.5 & 0 & 0 & 0 & 0 & 0 & 0 & 0.8 & 5.5 \\
\hline 04 & 14.3 & 31.4 & 34.1 & 15.2 & 0 & 0 & 0 & 0 & 0 & 0 & 0.7 & 6.9 \\
\hline 05 & 15.7 & 34.4 & 34.9 & 14.2 & 0 & 0 & 0 & 0 & 0 & 0 & 0.9 & 6.1 \\
\hline 06 & 15.4 & 33.8 & 34.3 & 12 & 0 & 0 & 0 & 0 & 0 & 0 & 0.7 & 7.1 \\
\hline 07 & 14.7 & 33.3 & 33.9 & 10.3 & 0 & 0 & 0 & 0 & 0 & 0 & 1.7 & 7.9 \\
\hline 08 & 14.8 & 33 & 33.1 & 9.2 & 0 & 0 & 0 & 0 & 0 & 0 & 0.7 & 10.8 \\
\hline 09 & 16.1 & 33 & 32.2 & 9.2 & 0 & 0 & 0 & 0 & 0 & 0.1 & 0.5 & 10.8 \\
\hline 10 & 17.5 & 33.3 & 31.1 & 7.5 & 0 & 0 & 0 & 0 & 0 & 0.1 & 0.6 & 10.3 \\
\hline 11 & 17.6 & 33.1 & 30.5 & 6.6 & 0 & 0 & 0 & 0 & 0 & 0 & 0.4 & 11 \\
\hline 12 & 18.1 & 33.3 & 30.2 & 6 & 0 & 0 & 0 & 0 & 0 & 0 & 0.9 & 10.7 \\
\hline
\end{tabular}




\begin{tabular}{|c|c|c|c|c|c|c|c|c|c|c|c|c|}
13 & 19.4 & 32.9 & 30.2 & 4.8 & 0 & 0 & 0 & 0 & 0 & 0 & 1 & 11.2 \\
\hline 14 & 19.4 & 33 & 29.6 & 3.6 & 0 & 0 & 0 & 0 & 0 & 0 & 1.2 & 11.1 \\
\hline 15 & 19.8 & 33.6 & 30.5 & 2.4 & 0 & 0 & 0 & 0 & 0 & 0 & 1.3 & 10.2 \\
\hline 16 & 21.5 & 33.5 & 30.9 & 0.8 & 0 & 0 & 0 & 0 & 0 & 0 & 1.6 & 9.6 \\
\hline 17 & 22.6 & 33.3 & 30 & 0 & 0 & 0 & 0 & 0 & 0 & 0 & 2.2 & 9.6 \\
\hline 18 & 23.6 & 33.9 & 29.4 & 0 & 0 & 0 & 0 & 0 & 0 & 0 & 1.9 & 9 \\
\hline 19 & 24.3 & 34 & 28.9 & 0 & 0 & 0 & 0 & 0 & 0 & 0 & 1 & 10.5 \\
\hline 20 & 24.8 & 34.5 & 29.2 & 0 & 0 & 0 & 0 & 0 & 0 & 0.5 & 0.5 & 10.6 \\
\hline 21 & 26.2 & 34.6 & 29.9 & 0.1 & 0 & 0 & 0 & 0 & 0 & 0 & 0.7 & 11.4 \\
\hline 22 & 26.8 & 34.6 & 28.5 & 0 & 0 & 0 & 0 & 0 & 0 & 0 & 0.8 & 13.1 \\
\hline 23 & 27 & 35.9 & 27.7 & 0 & 0 & 0 & 0 & 0 & 0 & 0 & 1.5 & 14.3 \\
\hline 24 & 27.4 & 35.5 & 27.1 & 0 & 0 & 0 & 0 & 0 & 0 & 0 & 1.3 & 14.1 \\
\hline 25 & 28.3 & 34.9 & 28.6 & 0 & 0 & 0 & 0 & 0 & 0 & 0 & 1.4 & 14.3 \\
\hline 26 & 28 & 34.7 & 29.1 & 0 & 0 & 0 & 0 & 0 & 0 & 0 & 1.3 & 15 \\
\hline 27 & 28.3 & 34.7 & 28.5 & 0 & 0 & 0 & 0 & 0 & 0 & 0.1 & 2.3 & 13.7 \\
\hline 28 & 27.8 & 34.4 & 27.4 & 0 & 0 & 0 & 0 & 0 & 0 & 1.3 & 3.1 & 12.8 \\
\hline 29 & 28 & & 25.3 & 0 & 0 & 0 & 0 & 0 & 0 & 0.5 & 4.6 & 12.4 \\
\hline 30 & 28.1 & & 23.2 & 0 & 0 & 0 & 0 & 0 & 0 & 0.8 & 5.1 & 14 \\
\hline 31 & 29.9 & & 22.7 & & 0 & & 0 & 0 & & 0.7 & & 14.7 \\
\hline
\end{tabular}

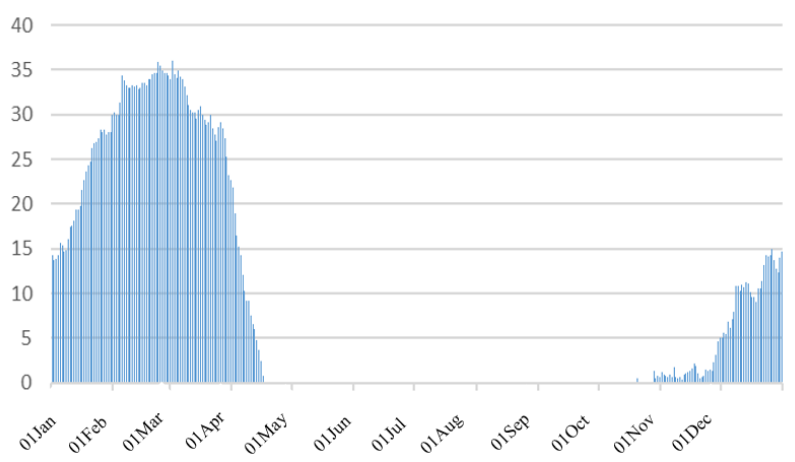

Fig. 13. Average snow depth (m)

\subsection{Wind speed and direction}

Table 15. Average wind speeds $(\mathrm{m} / \mathrm{s})$

\begin{tabular}{|c|c|c|c|c|c|c|c|c|c|c|c|c|}
\hline $\begin{array}{c}\text { Day } \backslash \\
\text { Month }\end{array}$ & January & February & March & April & May & June & July & August & Sept. & Oct. & Nov. & Dec \\
\hline 01 & 1.0 & 1.4 & 1.2 & 1.7 & 1.6 & 1.2 & 0.9 & 0.8 & 1.1 & 1.3 & 1.3 & 1.3 \\
\hline 02 & 1.3 & 1.3 & 1.5 & 1.7 & 1.1 & 1.2 & 0.8 & 0.9 & 0.6 & 1.2 & 1.1 & 1.2 \\
\hline 03 & 1.4 & 1.2 & 1.4 & 1.5 & 1.3 & 1.0 & 0.9 & 1.0 & 0.9 & 0.9 & 1.0 & 1.2 \\
\hline 04 & 1.2 & 1.6 & 1.5 & 1.5 & 1.1 & 1.3 & 1.1 & 1.0 & 1.0 & 1.0 & 1.1 & 1.4 \\
\hline 05 & 1.5 & 1.4 & 1.3 & 1.2 & 1.3 & 1.4 & 1.1 & 1.1 & 1.1 & 1.2 & 1.2 & 1.4 \\
\hline 06 & 1.6 & 1.2 & 1.3 & 1.0 & 1.4 & 1.3 & 1.0 & 0.7 & 0.9 & 1.2 & 1.2 & 1.4 \\
\hline 07 & 1.7 & 1.1 & 1.5 & 1.2 & 0.9 & 1.1 & 0.8 & 0.7 & 0.7 & 1.0 & 1.1 & 1.3 \\
\hline 08 & 1.4 & 1.3 & 1.2 & 0.9 & 0.9 & 1.1 & 1.0 & 0.9 & 0.8 & 1.0 & 1.2 & 1.3 \\
\hline 09 & 1.1 & 1.8 & 1.3 & 1.2 & 1.4 & 1.2 & 0.8 & 0.8 & 0.7 & 1.1 & 1.2 & 1.2 \\
\hline 10 & 1.0 & 2.0 & 1.2 & 1.5 & 1.1 & 0.7 & 1.0 & 0.6 & 0.8 & 0.9 & 1.4 & 1.5 \\
\hline 11 & 0.9 & 1.6 & 1.2 & 1.4 & 0.9 & 1.1 & 0.9 & 0.7 & 0.7 & 1.0 & 1.5 & 1.2 \\
\hline 12 & 1.3 & 1.5 & 1.3 & 1.0 & 1.2 & 1.1 & 1.1 & 0.8 & 0.7 & 0.9 & 1.4 & 1.3 \\
\hline 13 & 1.5 & 1.4 & 1.4 & 1.0 & 1.2 & 1.0 & 1.0 & 0.8 & 0.7 & 1.1 & 1.2 & 1.4 \\
\hline 14 & 1.3 & 1.7 & 1.2 & 1.0 & 1.1 & 0.8 & 0.7 & 1.0 & 0.9 & 0.9 & 1.4 & 1.4 \\
\hline 15 & 0.9 & 1.4 & 1.3 & 0.9 & 1.0 & 1.0 & 0.8 & 1.0 & 0.9 & 1.2 & 1.2 & 1.1 \\
\hline 16 & 1.0 & 1.3 & 1.2 & 1.3 & 1.2 & 0.9 & 0.8 & 0.9 & 0.8 & 1.1 & 1.1 & 1.1 \\
\hline 17 & 1.3 & 1.5 & 1.3 & 0.8 & 1.5 & 1.1 & 0.9 & 1.1 & 0.8 & 1.0 & 1.2 & 1.4 \\
\hline 18 & 1.1 & 1.1 & 1.4 & 1.5 & 1.2 & 0.9 & 1.0 & 1.0 & 0.8 & 1.0 & 1.4 & 1.4 \\
\hline 19 & 1.3 & 1.0 & 1.3 & 2.0 & 1.0 & 0.9 & 1.0 & 0.8 & 0.7 & 1.0 & 1.3 & 1.2 \\
\hline 20 & 1.2 & 1.2 & 1.1 & 1.7 & 0.9 & 1.2 & 1.0 & 1.0 & 0.6 & 0.9 & 1.3 & 1.2 \\
\hline 21 & 1.1 & 1.0 & 1.2 & 1.8 & 0.9 & 1.1 & 1.0 & 1.3 & 0.9 & 1.0 & 1.3 & 1.3 \\
\hline 22 & 1.2 & 1.3 & 1.5 & 1.6 & 0.9 & 1.3 & 0.9 & 1.1 & 0.9 & 1.3 & 1.3 & 1.0 \\
\hline 23 & 1.3 & 1.1 & 1.5 & 1.5 & 1.0 & 1.0 & 1.0 & 1.1 & 1.1 & 1.3 & 1.0 & 1.1 \\
\hline 24 & 1.2 & 1.2 & 1.7 & 1.5 & 1.1 & 0.7 & 0.9 & 0.9 & 1.1 & 1.1 & 1.1 & 1.4 \\
\hline 25 & 1.3 & 1.3 & 1.7 & 1.4 & 1.1 & 0.8 & 0.9 & 0.8 & 1.0 & 1.2 & 1.1 & 1.2 \\
\hline 26 & 0.9 & 1.2 & 1.8 & 1.5 & 0.9 & 1.0 & 1.0 & 0.9 & 1.2 & 1.2 & 1.4 & 1.3 \\
\hline 27 & 0.7 & 1.3 & 1.5 & 1.0 & 1.4 & 1.1 & 0.9 & 0.6 & 0.9 & 1.3 & 1.3 & 1.1 \\
\hline 28 & 1.0 & 1.4 & 1.8 & 1.2 & 1.0 & 1.3 & 0.8 & 0.7 & 0.9 & 1.2 & 1.4 & 1.2 \\
\hline 29 & 1.4 & & 1.7 & 1.3 & 0.9 & 1.1 & 1.0 & 1.1 & 1.1 & 1.5 & 1.5 & 1.7 \\
\hline 30 & 1.4 & & 1.6 & 1.3 & 1.2 & 1.1 & 0.8 & 1.2 & 1.2 & 1.5 & 1.4 & 1.4 \\
\hline 31 & 1.5 & & 1.5 & & 1.2 & & 0.8 & 1.0 & & 1.4 & & 1.1 \\
\hline
\end{tabular}




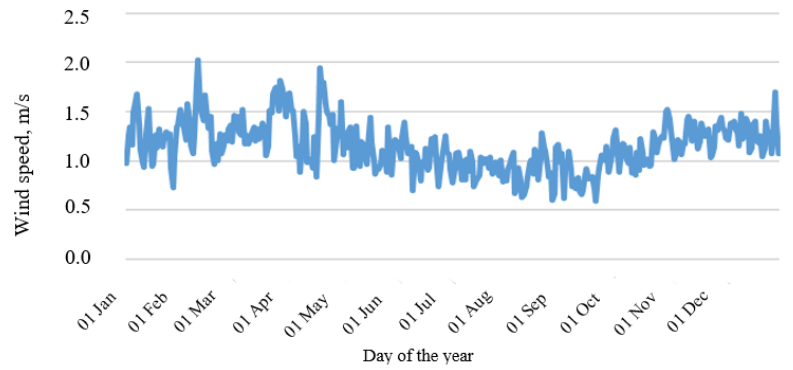

Fig. 14. Average wind speed (annual course)

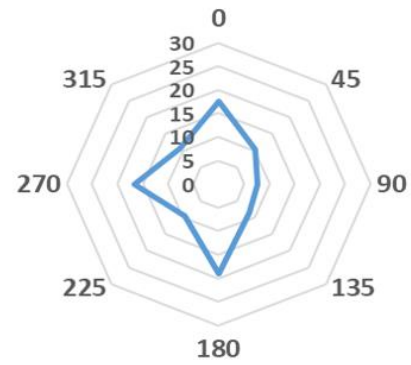

Fig. 15. Wind rose in Moscow (2009-2018)

Table 16. Relative air humidity (\%)

\begin{tabular}{|c|c|c|c|c|c|c|c|c|c|c|c|c|}
\hline $\begin{array}{c}\text { Day } \backslash \\
\text { Month }\end{array}$ & January & February & March & April & May & June & July & August & Sept. & Oct. & Nov. & Dec. \\
\hline 01 & 87 & 81 & 79 & 77 & 57 & 60 & 62 & 67 & 79 & 77 & 81 & 86 \\
\hline 02 & 88 & 82 & 82 & 77 & 57 & 60 & 68 & 68 & 79 & 80 & 80 & 87 \\
\hline 03 & 85 & 84 & 80 & 76 & 60 & 63 & 68 & 68 & 80 & 79 & 88 & 84 \\
\hline 04 & 86 & 83 & 80 & 66 & 62 & 62 & 66 & 68 & 81 & 82 & 85 & 88 \\
\hline 05 & 85 & 79 & 82 & 71 & 66 & 63 & 69 & 67 & 82 & 82 & 82 & 87 \\
\hline 06 & 85 & 81 & 77 & 67 & 67 & 65 & 65 & 67 & 83 & 81 & 84 & 86 \\
\hline 07 & 83 & 81 & 74 & 73 & 60 & 68 & 71 & 69 & 80 & 81 & 87 & 85 \\
\hline 08 & 84 & 83 & 76 & 67 & 62 & 66 & 74 & 69 & 79 & 83 & 89 & 86 \\
\hline 09 & 85 & 85 & 72 & 64 & 58 & 70 & 76 & 66 & 80 & 82 & 88 & 88 \\
\hline 10 & 86 & 83 & 68 & 62 & 61 & 72 & 77 & 70 & 79 & 79 & 88 & 89 \\
\hline 11 & 88 & 83 & 70 & 59 & 60 & 73 & 73 & 72 & 81 & 78 & 87 & 87 \\
\hline 12 & 87 & 81 & 73 & 59 & 61 & 69 & 67 & 70 & 77 & 84 & 85 & 87 \\
\hline 13 & 84 & 83 & 70 & 64 & 60 & 71 & 71 & 68 & 77 & 83 & 83 & 87 \\
\hline 14 & 84 & 84 & 68 & 66 & 59 & 71 & 69 & 72 & 80 & 81 & 85 & 84 \\
\hline 15 & 87 & 83 & 70 & 64 & 66 & 73 & 69 & 74 & 76 & 84 & 82 & 87 \\
\hline 16 & 86 & 82 & 74 & 72 & 72 & 74 & 66 & 75 & 79 & 81 & 82 & 89 \\
\hline 17 & 86 & 79 & 71 & 66 & 75 & 68 & 68 & 73 & 79 & 82 & 84 & 88 \\
\hline 18 & 86 & 80 & 70 & 68 & 71 & 62 & 71 & 71 & 77 & 79 & 82 & 87 \\
\hline 19 & 82 & 82 & 76 & 56 & 70 & 69 & 72 & 70 & 76 & 79 & 88 & 88 \\
\hline 20 & 83 & 82 & 76 & 60 & 67 & 65 & 76 & 74 & 79 & 80 & 85 & 86 \\
\hline 21 & 85 & 83 & 77 & 61 & 65 & 69 & 75 & 71 & 79 & 82 & 86 & 87 \\
\hline 22 & 85 & 81 & 72 & 64 & 69 & 67 & 73 & 72 & 80 & 76 & 82 & 85 \\
\hline 23 & 84 & 81 & 66 & 61 & 74 & 68 & 66 & 74 & 82 & 79 & 82 & 89 \\
\hline 24 & 85 & 82 & 66 & 58 & 72 & 68 & 67 & 75 & 84 & 81 & 88 & 85 \\
\hline 25 & 81 & 75 & 65 & 61 & 68 & 72 & 67 & 75 & 83 & 77 & 87 & 88 \\
\hline 26 & 80 & 71 & 59 & 60 & 66 & 68 & 66 & 73 & 76 & 76 & 88 & 89 \\
\hline 27 & 83 & 73 & 57 & 66 & 67 & 69 & 68 & 75 & 75 & 81 & 86 & 86 \\
\hline 28 & 84 & 74 & 58 & 62 & 72 & 66 & 70 & 77 & 82 & 84 & 87 & 85 \\
\hline 29 & 83 & 77 & 60 & 52 & 73 & 62 & 66 & 76 & 83 & 78 & 85 & 86 \\
\hline 30 & 83 & & 66 & 58 & 65 & 64 & 68 & 76 & 79 & 76 & 85 & 88 \\
\hline 31 & 83 & & 77 & & 62 & & 67 & 78 & & 82 & & 84 \\
\hline
\end{tabular}




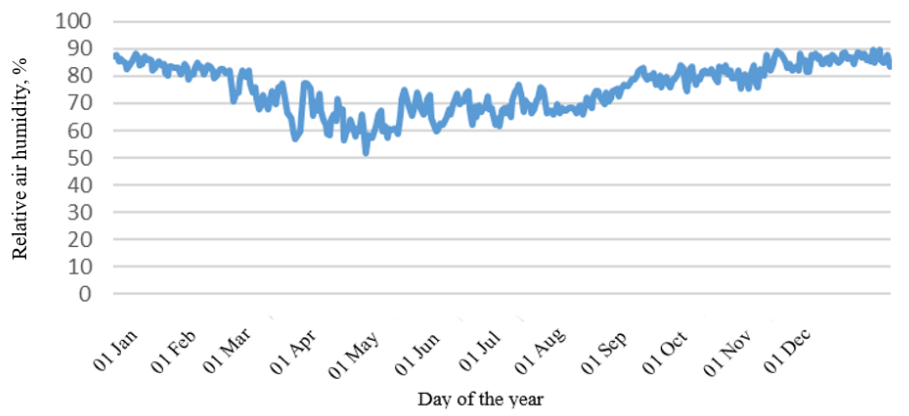

Fig. 16. Relative air humidity (\%)

\subsection{The heating period duration in Moscow.}

Table 17. Heating period duration of the (days)

\begin{tabular}{|c|c|c|c|c|c|}
\hline Period & Start & Finish & $\begin{array}{c}\text { Add.period } \\
\text { (Start) }\end{array}$ & $\begin{array}{c}\text { Add.period } \\
\text { (Finish) }\end{array}$ & $\begin{array}{c}\text { Duration } \\
\text { (days) }\end{array}$ \\
\hline $2009-2010$ & 29.09 .2009 & 01.05 .2010 & - & - & 214 \\
\hline $2010-2011$ & 28.09 .2010 & 28.04 .2011 & - & - & 212 \\
\hline $2011-2012$ & 28.09 .2011 & 22.04 .2012 & - & - & 207 \\
\hline $2012-2013$ & 06.10 .2012 & 30.04 .2013 & - & - & 206 \\
\hline $2013-2014$ & 21.09 .2013 & 30.04 .2014 & - & - & 221 \\
\hline $2014-2015$ & 25.09 .2014 & 30.04 .2015 & - & - & 217 \\
\hline $2015-2016$ & 04.10 .2015 & 03.05 .2016 & - & - & 212 \\
\hline $2016-2017$ & 20.09 .2016 & 01.05 .2017 & 09.05 .2017 & 18.05 .2017 & 232 \\
\hline $2017-2018$ & 28.09 .2017 & 29.04 .2018 & - & - & 213 \\
\hline
\end{tabular}

\subsection{The number of degree-hours throughout the heating period (HP).}

Table 18. Degree-hours throughout the heating period.

\begin{tabular}{|c|c|c|c|c|}
\hline Period & $\begin{array}{c}\text { Av.heating period } \\
\text { temperature, }{ }^{0} \mathrm{C}\end{array}$ & $\begin{array}{c}\text { Duration, } \\
\text { days }\end{array}$ & $\begin{array}{c}\text { The number of } \\
\text { degree-days }\end{array}$ & $\begin{array}{c}\text { The number of } \\
\text { degree-hours }\end{array}$ \\
\hline $2009-2010$ & -1.8 & 214 & 42.8 & 1027.2 \\
\hline $2010-2011$ & -2.1 & 212 & -21.2 & -508.8 \\
\hline $2011-2012$ & -1.4 & 207 & 124.2 & 2980.8 \\
\hline $2012-2013$ & -2.2 & 206 & -41.2 & -988.8 \\
\hline $2013-2014$ & 1.4 & 221 & 751.4 & 18033.6 \\
\hline $2014-2015$ & 0.2 & 217 & 477.4 & 11457.6 \\
\hline $2015-2016$ & 0.5 & 212 & 530 & 12720 \\
\hline $2016-2017$ & 0.1 & 232 & 487.2 & 11692.8 \\
\hline $2017-2018$ & -0.7 & 213 & 276.9 & 6645.6 \\
\hline average & -0.7 & 214.9 & 291.9 & 7006.7 \\
\hline
\end{tabular}

\subsection{Crossings through $-2{ }^{\circ} \mathrm{C}$.}

Table 19. The number of periods with an average daily temperature above $-2^{\circ} \mathrm{C}$ during the heating seasons

\begin{tabular}{|c|c|c|c|c|}
\hline Heating season & Number of seasons & Degree-days & Degree-hours & Duration, days \\
\hline $2009-2010$ & 8 & 595.2 & 14284.8 & 124 \\
\hline $2010-2011$ & 11 & 478.8 & 11491.2 & 84 \\
\hline $2011-2012$ & 14 & 673.1 & 16154.4 & 127 \\
\hline $2012-2013$ & 14 & 605 & 14520 & 110 \\
\hline
\end{tabular}




\begin{tabular}{|c|c|c|c|c|}
\hline $2013-2014$ & 13 & 1089.9 & 26157.6 & 173 \\
\hline $2014-2015$ & 14 & 480.6 & 11534.4 & 89 \\
\hline $2015-2016$ & 9 & 826.8 & 19843.2 & 156 \\
\hline $2016-2017$ & 19 & 742.4 & 17817.6 & 128 \\
\hline $2017-2018$ & 10 & 694.4 & 16665.6 & 124 \\
\hline Total & 112 & 6186.2 & 148468.7 & 1115 \\
\hline Average per year & 12 & 687.4 & 16496.5 & 124 \\
\hline
\end{tabular}

Table 20. The number of periods with an average daily temperature below $-2^{\circ} \mathrm{C}$ during the heating seasons

\begin{tabular}{|c|c|c|}
\hline Heating season & Number of periods & Duration, days \\
\hline $2009-2010$ & 7 & 90 \\
\hline $2010-2011$ & 10 & 128 \\
\hline $2011-2012$ & 13 & 80 \\
\hline $2012-2013$ & 13 & 96 \\
\hline $2013-2014$ & 12 & 48 \\
\hline $2014-2015$ & 13 & 128 \\
\hline $2015-2016$ & 8 & 56 \\
\hline $2016-2017$ & 17 & 104 \\
\hline $2017-2018$ & 9 & 89 \\
\hline Total & 102 & 819 \\
\hline Average per year & 11 & 91 \\
\hline
\end{tabular}

Table 21. The number of periods with an average daily temperature below $5^{\circ} \mathrm{C}$ and above $-3^{\circ} \mathrm{C}$, and with a relative air humidity of more than $60 \%$ during the heating seasons

\begin{tabular}{|c|c|c|}
\hline Season & Number of periods & Duration, days \\
\hline $2009-2010$ & 19 & 65 \\
\hline $2010-2011$ & 16 & 88 \\
\hline $2011-2012$ & 16 & 105 \\
\hline $2012-2013$ & 18 & 77 \\
\hline $2013-2014$ & 18 & 104 \\
\hline $2014-2015$ & 19 & 199 \\
\hline $2015-2016$ & 19 & 99 \\
\hline $2016-2017$ & 26 & 87 \\
\hline $2017-2018$ & 16 & 87 \\
\hline Total & 167 & 911 \\
\hline Average per year & 19 & 101 \\
\hline
\end{tabular}

\section{Conclusion}

The data on average daily outdoor temperatures, sunshine duration, snow depth, wind speed, etc. are presented. The number of hours and degrees-hours of the heating season with temperatures exceeding minus $2^{\circ} \mathrm{C}$ is determined, as well as the ratio of periods (degreeshours) with temperatures above and below minus $2^{\circ} \mathrm{C}$.

The data of a typical climatic year by region showed the following: the maximum monthly average values in St. Petersburg are observed in July-August $\left(23^{\circ} \mathrm{C}\right)$, the minimum are in January $\left(-10^{\circ} \mathrm{C}\right)$. In Moscow, the maximum values in July are $22.8^{\circ} \mathrm{C},-11.6^{\circ} \mathrm{C}$ in January.

The data on relative humidity above $60 \%$ and the moisture content of atmospheric air in two regions are also presented in the research. Periods with an average daily relative humidity above $60 \%$ at a temperature between $+5^{\circ} \mathrm{C}$ and $-3^{\circ} \mathrm{C}$ during the heating season (the number of such periods) are represented as well. It was established that the maximum number of days of such periods in Moscow during the heating season was observed in 2014-2015, and the minimum in 2009-2010. For St. Petersburg, the greatest value was observed during the heating season 2016-2017, the smallest was for 2017-2018. [8-9] 


\section{Acknowledgement}

The research was conducted by JSC "INSOLAR-INVEST" with the financial support of the Ministry of Education and Science of Russian Federation. Unique identifier of the project RFMEFI57918X0159.

\section{References}

1. I.B. Belikov, E.V. Gorbarenko et al., , Ekologo-klimaticheskie kharakteristiki atmosfery V 2010 g. po dannym meteorologicheskoi observatorii MGU (Moskva MAKS Press, 2011).

2. V.N. Kedrolivanskii Meteorologicheskie pribory. (Moscow, GUGMS, 1937).

3. Nastavlenie gidrometeorologicheskim stantsiiam i postam. 3(1). (Leningrad, Gidrometeoizdat, 1969).

4. Spravochnik po gidrometeorologicheskim priboram i ustanovkam. (Leningrad, Gidrometeoizdat, 1971).

5. Spravochnik ekologo-klimaticheskikh kharakteristik g. Moskvy (po nabliudeniiam Meteorologicheskoi observatorii MGU), 1, (Moscow, MGU, 2003).

6. M. A. Lokoshchenko, E. Iu. Zhdanova et al., Ekologo-klimaticheskie kharakteristiki atmosfery Moskvy v 2017 g. po dannym Meteorologicheskoi observatorii MGU imeni M.V.Lomonosova. (Moscow, 2018).

7. G.P. Vasilyev, V.F. Gornov et al., Inzhenerno-stroitelnyi zhurnal. 4 (72), 62-72 (2017).

8. G.P. Vasilyev, N.V. Peskov et al., MATEC Web of Conferences 30. 05003 (2015).

9. G.P. Vasilyev, V.A. Leskov et al., MATEC Web of Conferences 30. 05001 (2015).

10. G.P. Vasilyev, V.F. Gornov, M.V. Kolesova IOP Conference Series: Earth and Environmental Science. 249, 012033 (2019). 